\title{
Range extension of the mud crab Eurypanopeus depressus (Smith, 1869) (Decapoda, Panopeidae): A new record for the coastal south of Brazil
}

\author{
Marcos A. Rodrigues ${ }^{1,2}$, Rony R.R. Vieira ${ }^{1}$ \& Fernando D'Incao ${ }^{1}$ \\ ${ }^{1}$ Laboratório de Crustáceos Decápodos, Instituto de Oceanografia, Universidade do Rio Grande (FURG), \\ PO Box 474, Rio Grande, 96201-900, RS, Brazil. \\ ${ }^{2}$ Corresponding author: Marcos A. Rodrigues, e-mail: alanizmarcos@gmail.com
}

\begin{abstract}
RODRIGUES, M.A., VIEIRA, R.R.R., D'INCAO, F. Range extension of the mud crab Eurypanopeus depressus (Smith, 1869) (Decapoda, Panopeidae): A new record for the coastal south of Brazil. Biota Neotropica. 14(1): e20130063. http://www.biotaneotropica.org.br/v14n1/en/abstract?short-communica tion+bn00814012014
\end{abstract}

\begin{abstract}
The discovery of Eurypanopeus depressus (Decapoda: Panopeidae; Smith, 1869) on the coast of Rio Grande do Sul, Brazil suggests that the species was recently introduced, possibly due to different sources of introduction, such as the ballast water of ships. E. depressus were collected using otter-trawl net in the Patos Lagoon Estuary. Discussion focuses on the fact that the primary South American distribution derives from Uruguayan shores, and later expanded to nearby places (Brazil and Argentina). This work extends the Southern Hemisphere distribution for the species, as it was previously reported only from Argentina to Uruguay.
\end{abstract}

Keywords: range distribution, bioinvasion, ecology, systematics.

RODRIGUES, M.A., VIEIRA, R.R.R., D'INCAO, F. Expansão da distribuição do caranguejo Eurypanopeus depressus (Smith, 1869) (Decapoda, Panopeidae). Um novo registro para a costa do sul do Brasil. Biota Neotropica. 14(1): e20130063. www.biotaneotropica.org.br/v14n1/pt/abstract?short-communication+bn00814012014

Resumo: O registro de Eurypanopeus depressus (Smith, 1869) na costa do Rio Grande do Sul, Brasil (Decapoda:Xanthidae) levanta a hipótese de que a espécie pode ser invasora, devido a diferentes fontes de introdução como água de lastro. E. depressus foi coletada com rede de portas no estuário da Lagoa dos Patos. A discussão foca no fato de que a distribuição primária da espécie na América do Sul pode ter sido na costa uruguaia, tendo esta posteriormente se irradiado para locais próximos (Brasil e Argentina). Este trabalho estende a distribuição da espécie no hemisfério sul, já que previamente era citada somente para a Argentina e Uruguai.

Palavras-chave: intervalo de distribuição, bioinvasão, ecologia, sistemática.

\section{Introduction}

Eurypanopeus depressus, also known as the flat mud crab, or depressed mud crab, is common along the East and Gulf coasts of North America from Massachusetts to Florida and Texas. It lives in subtidal or intertidal oyster beds, and has been reported from depths ranging from 1 to 27 meters (Grant \& McDonald 1979, Sulkin et al. 1983, Williams 1984). The species is also found in the Dutch West Indies and Bermuda and, in South America, Eurypanopeus depressus has been recorded in Uruguay and Argentina, with the latter record from Mar Chiquita, a warmtemperate coastal lagoon south of Rio de la Plata, Its occurrence in South America is probably due to introduction (Williams 1984, Spivak \& Luppi 2005, Tavares 2011).

This study presents information about the presence of E. depressus in the Patos Lagoon Estuary (Brazil), one of the biggest lagoons in the world, and discusses the role of ballast water in transporting species, and other ways of introduction.

\section{Material and methods}

Specimens presented in this article were collected during several projects of the "Laboratório de Crustáceos Decápodos", from 1980 through 2012, and the general sampling method consisted of a 5-minute tow using an ottertrawl net, with $13 \mathrm{~mm}$ distance between opposite knots, towed at an average speed of 2.0 knots. Sampling locations included the "Saco da Mangueira" inlet, on the Patos Lagoon Estuary (Rio Grande do Sul, Brazil), the "Ilha dos Marinheiros" island and the breakwater that marks the entrance to the estuary. Specimens were identified using the descriptions published by Rathbun (1930), and reviewed by Williams (1984). Ryan (1965) describes an alcohol persistent red spot in the inner surface of the ischium of the third maxillipeds of both sexes as a recognition character, but it is also present on Panopeus herbstii H.Milne Edwards 1834 (Williams 1984). The analyzed material is currently deposited in the scientific collection of the "Laboratório de Crustáceos Decápodes" laboratory, at the 
Oceanographic Institute of the University of Rio Grande (FURG).

\section{Results}

Systematics

Section Eubrachyura Saint Laurent, 1980

Subsection Heterotremata Guinot, 1977

Infraorder Brachyura Linnaeus, 1758

Family Panopeidae Ortmann, 1893

Subfamily Panopeinae Ortmann, 1893

Eurypanopeus depressus (Smith, 1869) (Fig. 1)

Sinonym: Williams 1984, Nizinski 2003, Spivak \& Luppi 2005;

Distribution: Massachusetts Bay through Florida, to southern Texas; "Dutch West Indies" (now Netherlands Antilles), Bermuda, Uruguay, Mar Chiquita on Argentina and Patos Lagoon estuary, Brazil (Juanicó 1978, Williams 1984, Spivak \& Luppi 2005, present study).

Material Examined: BRAZIL, Rio Grande do Sul, Lagoa dos Patos. "Molhe Oeste": 5 males (CW 6.34, 7.44, 6.94, 7.83 and 6.92), 8 females (CW 8.67, 8.24, 5.47, 8.09, 7.30, 7.24, 5.91 and 7.29), 13/III/1985, coll. Capitoli, P.R. (FURG - 2990). Rio Grande do Sul, Lagoa dos Patos. "Molhe Leste": 2 males (CW 7.72 and 5.38), 1 female (CW 7.30), 12/V/1985, coll. Capitoli, P.R. (FURG - 3143). Rio Grande do Sul, Lagoa dos Patos. "Saco da Mangueira" inlet: 1 male (CW 14.88), 11/V/1999 (FURG - 2792). Rio Grande do Sul, Lagoa dos Patos. "Saco da Mangueira" inlet: 1 female (CW 6.01), 12/V/1999 (FURG2782). Rio Grande do Sul, Lagoa dos Patos. "Saco da Mangueira" inlet: 1 male (CW 12.21), 15/VII/1999 (FURG2973). Rio Grande do Sul, Lagoa dos Patos. "Saco da Mangueira" inlet: 1 female (CW 8.08), 15/VII/1999 (FURG3035). Rio Grande do Sul, Lagoa dos Patos. "Ilha dos Marinheiros" island: 2 males (CW 11.3, 3.9), 13 females (CW $4.1,4.2,4.5,3.5,4.5,5.3,5.4,3.4,6.1,5.1,5.5,3.4,2.6) 04 / \mathrm{VI} /$ 2012, coll. Rodrigues, M.A. (FURG-3289).
Description (Williams 1984): Carapace transversely oval, approximately $3 / 4$ as long as wide, flattened posteriorly, slightly convex in anterior half; aerolations well defined, finely granulate, with several pairs of transverse rows of granulations. Anterolateral teeth 4, outer margins curved granulate; first 2 teeth coalesced to form broad lobe with slightly sinuate margin; third tooth blunt or spine tipped; fourth and fifth spine tipped, pointing obliquely upward and forward. Front nearly straight, median notch small or absent. Chelipeds dissimilar and quite unequal. Smaller one more rugose than larger and with margin of fingers nearly straight and completely closing for considerable distance distally, opposed margins of tips thin edged and hollowed out - "spoon shaped". Larger chelipeds with nearly smooth articles, hand heavy and inflated; dactyl strongly curved, obscurely toothed at base and meeting fixed finger only at tip; internal tooth of carpus tipped with small spinule; in unworn condition both fingers show indication of possible flattening.

\section{Discussion}

The primary citation for E. depressus in the southern hemisphere is the work of Juanicó (1978), where the author indicates that although surprising, there is no doubt on the identification of the species, reported on the northern shores of the Rio de la Plata, from Montevideo to Piriápolis, Uruguay. More than an expansion of distribution, this can be interpreted as a record of a new geographic locality. The occurrence in the Patos Lagoon indicates that the La Plata River, which has been considered as a significant biogeographical barrier on the southwest Atlantic coast, might have allowed the expansion of the range of the species, possibly through larval transport due to advances from the river plume northward (Pimenta et al. 2008).

Although the species has been reported for Mar Chiquita in 2005 (Spivak \& Luppi 2005), the specimens examined for this study were sampled from 1985 through 2012. From its primary distribution in Uruguay, it is possible that E. depressus had

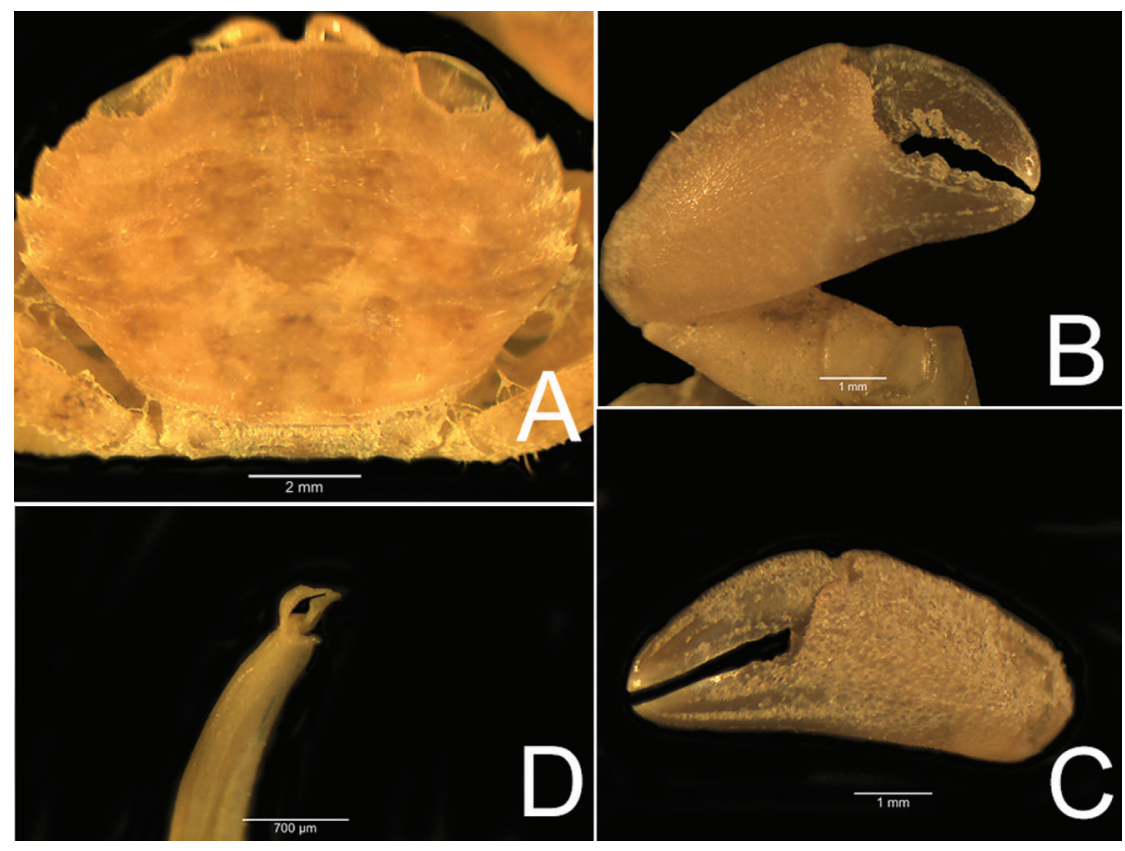

Figure 1. Eurypanopeus depressus (Smith, 1869). Male LCD n 3289 A: dorsal view; B: right pereopod (ventral view); C: left pereopod (ventral view); D: right gonopod. Scales are indicated. 
been collected later in Argentina than in the Patos Lagoon Estuary due to sampling efforts. Individuals collected by Juanicó (1978) are from 1954, prior to the sampling of the present article, and also from individuals collected on Argentina (Luppi et al. 2003).

The Patos Lagoon estuary can act as a barrier to the distribution of $E$. depressus to the north because of its conformation, with a high volume of freshwater discharged through the estuary mouth. Considered a "strangled" lagoon, the Patos Lagoon covers an area of $10.360 \mathrm{~km}^{2}$, with an average depth of $15 \mathrm{~m}$ and width of $800 \mathrm{~m}$ forming a huge body of water with only one opening to the sea, $\left(32^{\circ} 04^{\prime} 17^{\prime \prime} \mathrm{S}\right.$ $052^{\circ} 07^{\prime} 52^{\prime \prime} \mathrm{W}$ ) (Kjerfve 1986). Intense seaport movement from cargo shipping raises the problem of ballast water transport (Seeliger \& Costa 1997).

The species had been reported to the coast of Bahia in the 1980's (Gouvêa \& Leite 1980, Gouvêa 1986), but the identification is considered invalid, until consistent evidence is provided, as reported by Almeida \& Coelho (2008), which adds to this the fact that the individuals listed for the location are not available for reanalysis. The authors herein consider this citation as the first for the Brazilian coast.

New occurrences of species around the world have been well documented, and new territories are often reached by "doors" that are opened on determined biogeographic barriers, or by ship's ballast water transport. Most often this transport includes larvae, resistance eggs or juveniles, with the latter being the main source of species distribution changes on present days (Carlton \& Geller 1993, D’Incao \& Martins 1998).

Tavares (2011) suggests that the presence of E. depressus may be anthropogenic, because of the disjunct occurrence both in Argentina and in Uruguay. The species is commonly associated with oyster farms and artificial reefs (Williams 1984), but this does not explain the occurrence reported here, because there is no oyster culture on the Patos Lagoon estuary, as in the aforementioned countries. One of the possible explanations is introduction via ships ballast water. Highvolume of industrial sea-faring ship traffic has been responsible for the range expansion of several species of Brachyura, including Rhithropanopeus harrisii (Gould, 1865) Carcinus maenas (L.) and Charybdis hellerii (Milne Edwards, 1867) (D'Incao \& Martins 1998, Ferreira et al. 2001, Tavares 2011, Briski et al. 2012).

The definitive cause for the distribution of this species still remains unknown, but it can be speculated that water transport by ships may play a role on in its presence, since it is an effective dispersal method for aquatic organisms, and may have influenced the current geographic distribution of this species.

\section{Acknowledgements}

The authors are thankful to Dr. Gustavo Schmidt de Melo, for confirmation of the identification of the species, to Ashlee Lillis and Robert Dunn for the English review, and the two anonymous referees, for their contributions.

\section{References}

ALMEIDA, A.O. \& COELHO, P.A. 2008. Estuarine and marine brachyuran crabs (Crustacea: Decapoda) from Bahia, Brazil: checklist and zoogeographical considerations. Lat. Am. J. Aquat Res. 36(2):183-222. doi: http://dx.doi.org/10.3856/vol36-issue2-fulltext-4
BRISKI, E., GHABOOLI, S, BAILEY, S.A. \& MACISAAC, H.J. 2012. Invasion risk posed by macroinvertebrates transported in ships' ballast tanks. Biol. Inv. 14:1843-1850. doi: http://dx.doi.org/ 10.1007/s10530-012-0194-0

CARLTON, J.T. \& GELLER, J. 1993. Ecological roulette: the global transport and invasion of nonindigenous marine organisms. Science 261:78-82. doi: http://dx.doi.org/10.1126/science.261.5117.78

D'INCAO, F. \& MARTINS, S.T.S. 1998. Occurrence of Rhithropanopeus harrisii (Gould, 1841) in the Southern Coast of Brazil (Decapoda, Xanthidae). Nauplius 6:191-194.

FERREIRA, A.C., SANKARANKUTY, C., CUNHA, I.M.C., \& DUARTE. F.T. 2001. Yet another record of Charybdis hellerii (Milne Edwards, 1867) (Crustacea, Decapoda) from the Northeast of Brazil. Rev. Bras. Zool. 18(1):357-358. doi: http://dx.doi.org/ 10.1590/S0101-81752001000500034

GOUVÊA, E.P. \& LEITE Y.M. 1980. A Carcinofauna do Fital da Halimeda opuntia (Linnaeus) Lamoroux e a variação sazonal de sua densidade. Cienc. Cult. 32(5):596-600.

GOUVÊA, E.P. 1986. A Carcinofauna do Litoral Rochoso de Salvador, BA, e Alguns Aspectos Ecológicos. Cienc. Cult. 38(2):346-355.

GRANT J. \& MCDONALD. J. 1979. Dessication tolerance of Eurypanopeus depressus (Smith) (Decapoda: Xanthidae) and the exploitation of microhabitat. Estuaries 2:172-177. doi: http:// dx.doi.org/10.2307/1351731

JUANICÓ, M. 1978. Ampliación de la distribución geográfica de tres especies de Brachyura. Iheringia Ser. Zool. 51:45-46.

KJERFVE, B. 1986. Comparative Oceanography of Coastal Lagoons. In Estuarine variablity (D.A.Wolfe, ed.) Academic Press, New York, p.63-81.

LUPPI, T.A., BAS, C C. \& SPIVAK, D. 2003. The effect of temperature and salinity on larval development of Armases rubripes Rathbun, 1897 (Brachyura, Grapsoidea, Sesarmidae) and the southern limit of its geographical distribution. Estuar. Coast. Shelf Sci. 58:575-585. doi: http://dx.doi.org/10.1016/S0272-7714(03)00136-7

NIZINSKI, M. S. 2003. Annotated checklist of decapod crustaceans of Atlantic coastal and continental shelf waters of the United States. Proc. Biol. Soc. Wash. 116(1):96-157.

PIMENTA, F., GARVINE, R.W. \& MÜNCHOW, A. 2008. Observations of coastal upwelling off Uruguay downshelf of the Plata estuary, South America. J. Mar. Res. 66:835-872. doi: http:// dx.doi.org/10.1357/002224008788064577

RATHBUN, M. J. (1930). "The cancroid crabs of America." Bull. United States Nat. Mus. 152:1-608. doi: http://dx.doi.org/10.5479/ si.00963801.78-2851.1

RYAN, E.P. 1956. Observations on the life histories and the distribution of the Xanthidae (mud crabs) of Chesapeake Bay. Am. Midl. Nat. 56:138-162. doi: http://dx.doi.org/10.2307/2422450

SEELIGER, U. \& COSTA, C.S.B. 1997. Natural and Human Impact. In Subtropical Convergence Environments: The Coast and Sea in the Southwestern Atlantic (U. Seeliger, C. Odebrecht \& J.P. Castello, eds.). Springer, p.197-204.

SPIVAK, E. D. \& LUPPI. T.A. 2005. Southern range extension of two western Atlantic intertidal mud crabs: Panopeus meridionalis Williams, 1984 and Eurypanopeus depressus Smith, 1869 (Crustacea: Brachyura: Panopeidae) in Argentinian waters. Proc. Biol. Soc. Wash. 118(3):551-557. doi: http://dx.doi.org/10.2988/ 0006-324X(2005)118[551:SREOTW]2.0.CO;2

SULKIN SD, VAN HEUKELEM W.F. \& KELLY, P. 1983. Behavioral basis of depth regulation in hatching and post-larval stages of the mud crab Eurypanopeus depressus. Mar. Ecol. Prog. Ser. 11:157-164. doi: http://dx.doi.org/10.3354/meps011157

TAVARES M. 2011. Alien decapod crustaceans in the Southwestern Atlantic Ocean. In In the wrong place - alien marine crustaceans: distribution, biology and impacts (B.S. Galil, P.F. Clark \& J.T. Carlton eds.) Invading Nature - Springer Series in Invasion Ecology 6:251-268.

WILLIAMS, A.B. 1984. Shrimps, Lobsters and Crabs of the Atlantic Coast of the Eastern United States, Maine to Florida. Smithsonian Institution, Washington. 